\title{
Enhanced Anaerobic Digestion of Food Waste by Supplementing Trace Elements: Role of Selenium (VI) and Iron (II)
}

\author{
Javkhlan Ariunbaatar ${ }^{1 *}$, Giovanni Esposito ${ }^{1}$, Daniel H. Yeh ${ }^{2}$ and Piet N. L. Lens ${ }^{3}$ \\ ${ }^{1}$ Department of Civil and Mechanical Engineering, University of Cassino and Southern Lazio, Cassino, Italy, ${ }^{2}$ Department of \\ Civil and Environmental Engineering, University of South Florida, Tampa, FL, USA, ${ }^{3}$ UNESCO-IHE Institute for Water \\ Education, Delft, Netherlands
}

\section{OPEN ACCESS}

Edited by:

Prayad Pokethitiyook,

Mahidol University, Thailand

Reviewed by:

Sabine Kleinsteuber,

Helmholtz Centre for Environmental

Research, Germany

Guy Robert Lanza,

State University of New York, USA

*Correspondence:

Javkhlan Ariunbaatar

javkhlan.ariunbaatar@gmail.com

Specialty section:

This article was submitted to Microbiotechnology, Ecotoxicology and Bioremediation,

a section of the journal

Frontiers in Environmental Science

Received: 24 November 2015

Accepted: 28 January 2016

Published: 18 February 2016

Citation:

Ariunbaatar J, Esposito G, Yeh DH and Lens PNL (2016) Enhanced Anaerobic Digestion of Food Waste by Supplementing Trace Elements: Role of Selenium (VI) and Iron (II).

Front. Environ. Sci. 4:8.

doi: 10.3389/fenvs.2016.00008
This paper discusses the potential to enhance the anaerobic digestion of food waste FW by supplementing trace elements ( $\mathrm{Fe}, \mathrm{Co}, \mathrm{Ni}, \mathrm{Zn}, \mathrm{Mn}, \mathrm{Cu}, \mathrm{Se}$, and $\mathrm{Mo}$ ) individually as well as in cocktails. A series of batch experiments on the biomethane potential of synthetic food waste were performed with low (FW-A) and high (FW-B) trace element background concentrations prepared in, respectively, Delft (The Netherlands) and Tampa (Florida, USA). The most effective trace elements for FW-A were Fe with an increase of $39.2( \pm 0.6) \%$ of biomethane production, followed by Se (34.1 $\pm 5.6 \%$ increase), $\mathrm{Ni}$ (26.4 $\pm 0.2 \%$ increase) and Co (23.8 $\pm 0.2 \%$ increase). For FW-B supplementing these trace elements did not result in enhancement of the biomethane production, except for Se. FW-B had a Se concentration of $1.3( \pm 0.5) \mu \mathrm{g} / \mathrm{gTS}$, while it was below the detection limit for FW-A. Regardless of the FW source, Se resulted in 30-35\% increase of biomethane production at a concentration range of $25-50 \mu \mathrm{g} / \mathrm{L}(0.32-0.63 \mu \mathrm{M})$. Volatile fatty acids analysis revealed that TE supplementation enhances their consumption, thus yielding a higher biomethane production. Moreover, additional experiments on sulfide inhibition showed the enhancing effects of trace elements on the anaerobic digestion of food waste were not related with sulfide toxicity, but with the enzymatic reactions and/or microbial biomass aggregation.

Keywords: anaerobic digestion, food waste, trace element requirement, sulfide inhibition, selenium, iron

\section{INTRODUCTION}

Food waste (FW) is the largest fraction of municipal solid waste, and it was estimated that 1.3 billion tons of food is wasted every year (FAO, 2011). At present the most common FW stabilization technology is still landfilling. Landfilling is strongly discouraged by legislations such as the EU Directives on Landfill (1999/31/EC) and the Waste Framework (2006/12/EC), as it utilizes huge land areas and contributes to further environmental impacts including soil and groundwater pollution, greenhouse gases emissions (Ariunbaatar et al., 2014). Besides the environmental issues associated with FW, it is worth mentioning that $250 \mathrm{~km}^{3}$ of water and $28 \%$ of the world's agricultural area is used for the production of the 1.3 billion tons of FW (Parfit et al., 2010). It is thus important to recover and/or recycle waste to endorse responsible usage of natural resources. Therefore, anaerobic digestion (AD) of FW has become an important research field, as it couples 
waste stabilization to the production of energy as well as fertilizer (Zhang et al., 2011; Ariunbaatar et al., 2014).

FW contains easily biodegradable solids and a high water content, thus it serves as a perfect substrate for AD. Nevertheless, previous studies have shown that regardless of the inoculum origin, a prolonged operation of $\mathrm{AD}$ on $\mathrm{FW}$, even at low organic loading rates, could suffer from instability due to the increased inhibition by volatile fatty acids (VFA), ammonia and/or sulfide (Demirel and Scherer, 2011; Zhang et al., 2015). This instability is often linked with the lack of micronutrients or trace elements (TE; Demirel and Scherer, 2011; Banks et al., 2012; Zhang et al., 2015). The effects of TE to recover anaerobic digesters from failure have been studied extensively (Zhang et al., 2015). Supplementing TE does not only prevent and/or recover an inhibition; it can also enhance the $\mathrm{AD}$ process and yield a higher biomethane production.

To understand the roles of TE in an anaerobic system, the biochemical reaction and the anaerobic food web have always been the core of the research. It is well known that in anaerobic processes, TE generally act as: (1) micronutrients for various enzymatic reactions as co-factors; (2) promoters of microbial aggregation, which leads to an enhanced activity of the anaerobic microbes in case of syntrophy; (3) agents binding carriers-proteins and/or nutrients such as phosphates; (4) help to overcome sulfide toxicity through metal sulfide precipitation; (5) at higher concentrations TE can become toxicants to the microbial biomass (Takashima and Speece, 1989; Oleszkiewicz and Sharma, 1990; De Vrieze et al., 2013). These various effects of the TE depend on the environmental conditions, the background concentrations, bioavailability, and microbial uptake. Bioavailability of TE is often correlated with their speciation, which is the distribution of an element amongst different chemical species in a system (Worms et al., 2006; Ortner et al., 2015).

Various concentrations of different TE have been studied for the AD of FW. For instance, Zhang et al. (2011) used supplements of trace metals ( $\mathrm{Fe}, \mathrm{Co}, \mathrm{Mo}$, and $\mathrm{Ni}$ ) to stabilize a single-stage reactor treating $\mathrm{FW}$, and concluded that $\mathrm{Fe}$ was the most effective metal for a stable AD of FW. Similarly, De Vrieze et al. (2013) obtained a higher methane production from co-digestion of FW with an iron-rich activated sludge. Banks et al. (2012) found that adding Se and Co could recover a FW digester suffering from a propionic acid accumulation due to elevated ammonium concentrations. Facchin et al. (2013) achieved a $45-65 \%$ higher methane production yield from FW with supplementation of TE (Co, Mo, Ni, Se, and W) cocktail, and stressed the importance of Se and Mo for the biomethane production. Qiang et al. (2012) studied the requirements of $\mathrm{Fe}, \mathrm{Co}$, Ni for high-solid $\mathrm{FW}$ digestion $\left(6.3 \mathrm{kgCOD} / \mathrm{m}^{3} . \mathrm{d}\right)$; and calculated the theoretical values of $\mathrm{Fe}, \mathrm{Co}$, and $\mathrm{Ni}$ per gram of chemical oxygen demand (COD) of the FW to be 200.0, 6.0 , and $5.7 \mathrm{mg} / \mathrm{kgCOD}$, respectively. Nevertheless, none of the studies carried out a systematic experiment on the trace element benchmark concentrations for an enhancement or an inhibition of the biomethane production from FW.

This research aims at investigating the concentration range of the TE for an inhibition or enhancement for a typical
FW prepared in Delft (The Netherlands). A series of batch experiments on the biomethane potential (BMP) of a synthetic FW was conducted by supplementing cocktails of TE including cobalt, nickel, copper, manganese, iron, zinc, selenium, and molybdenum. The first set of BMP tests focused on the optimum concentrations of the TE supplementation for an enhancement of the BMP. The next set of experiments was carried out to determine the different effects of the TE individually or in groups. A follow-up experiment on the most important TE was conducted with FW prepared in Tampa (USA) using the same inoculum and experimental conditions. An additional experiment on hydrogen sulfide inhibition was conducted to elaborate the potential role of TE in alleviating hydrogen sulfide toxicity in the anaerobic process.

\section{MATERIALS AND METHODS}

\section{Substrate and Inoculum}

FW composition varies on many factors such as the region, season, culture, economic income, and demographics. To reduce experimental bias, the substrate used for this research was synthetically generated based on an average compositional analysis of FW in the EU, as it was used in previous research (Ariunbaatar et al., 2014, 2015). It contained 79\% fruits and vegetables, $5 \%$ pasta and rice, $6 \%$ bread and bakery, $8 \%$ meat and fish, 2\% dairy product (Ariunbaatar et al., 2014, 2015). A fresh substrate was prepared for each set of experiment using food bought from local supermarkets in Delft, The Netherlands (Albert Heijn) and Tampa, USA (Walmart). Although the same ingredients were used, the synthetic FW-A (prepared in Delft, The Netherlands) and FW-B (prepared in Tampa, USA) had differences in the TE background concentrations.

For all experiments, the same digestate from a full-scale mesophilic AD plant located in Capaccio-Salerno (Italy) was used as inoculum. The plant treats the buffalo dung together with the milk whey and sewage sludge generated from the mozzarella producing industry. It was used previously in studies of Ariunbaatar et al. $(2014,2015)$ and Liotta et al. (2015).

\section{Biomethane Potential Tests}

The biomethane potential (BMP) test of FW was conducted in duplicate serum bottles as described by Ariunbaatar et al. $(2014,2015)$. The substrate to inoculum ratio was $0.5 \mathrm{gVS} / \mathrm{gVS}$. Prior to starting the BMP test in an incubator controlled at mesophilic condition $\left(35 \pm 2^{\circ} \mathrm{C}\right)$, all BMP test bottles were flushed with nitrogen (or helium) gas to ensure anaerobic conditions. To maintain the initial total alkalinity (3.5-4.0 $\left.\mathrm{gCaCO}_{3} / \mathrm{L}\right)$ of the inoculum, sodium bicarbonate $\left(\mathrm{NaHCO}_{3}\right)$ was added to each bottle. The daily biomethane production was measured with the liquid displacement method using sodium hydroxide $(120 \mathrm{~g} / \mathrm{L})$ to absorb the carbon dioxide. The BMP test was continued for 20 days, as most $(80-85 \%)$ of the organics are converted to biomethane and the $\mathrm{AD}$ process reaches a plateau (Ariunbaatar et al., 2014, 2015). The normalized specific biomethane production (SBP) was calculated using the 
TABLE 1 | Trace elements groups used in this research.

\begin{tabular}{lccc}
\hline TE category & Oxidation state & Group number* & TE tested \\
\hline Metals & TE (II) & 1 & $\mathrm{Co} ; \mathrm{Ni}$ \\
& 2 & $\mathrm{Co} ; \mathrm{Ni} ; \mathrm{Fe}$ \\
& 3 & $\mathrm{Co} ; \mathrm{Ni} ; \mathrm{Fe} ; \mathrm{Zn}$ \\
Transition & $\mathrm{TE}(\mathrm{VI})$ & - & $\mathrm{Co}$; Ni; Fe; Zn; Mn; Cu \\
metals and/or & & & $\mathrm{Se} ; \mathrm{Mo}$ \\
metalloids & & &
\end{tabular}

*Group number refer to TE mixture.

net cumulative biomethane production (after deducting the biomethane production of the blank, i.e., the inoculum without substrate) and the initial VS added.

The first set of experiments was carried out to determine the concentration ranges for inhibition or enhancement of the $\mathrm{AD}$ process by adding a cocktail solution of TE. A stock solution of each TE $\left(\mathrm{NiCl}_{2} \cdot 6 \mathrm{H}_{2} \mathrm{O}, \mathrm{CuCl}_{2} \cdot 2 \mathrm{H}_{2} \mathrm{O}, \mathrm{MnCl}_{2} \cdot 2 \mathrm{H}_{2} \mathrm{O}, \mathrm{FeCl} 2 \cdot 4 \mathrm{H} 2 \mathrm{O}\right.$ $\mathrm{CoCl} 2 \cdot 6 \mathrm{H} 2 \mathrm{O}, \mathrm{ZnCl}_{2}, \mathrm{Na}_{2} \mathrm{SeO}_{4}, \mathrm{Na}_{2} \mathrm{MoO}_{4}$ ) was prepared. A cocktail solution containing all the TE was added to the bottles in eight different concentrations $(5,10,50,100,500 \mu \mathrm{g} / \mathrm{L}$, and $1,3,10 \mathrm{mg} / \mathrm{L})$. After determining the optimum enhancement concentration, a second set of experiments was carried out focusing on the different effects of the TE by grouping them based on their elemental category and/or their oxidation state as shown in Table 1. The effects of supplementing four different groups of TE (II): (1) Co, Ni; (2) Co, Ni, Fe; (3) Co, Ni, Fe, Zn; and (4) $\mathrm{Co}, \mathrm{Ni}, \mathrm{Fe}, \mathrm{Zn}, \mathrm{Mn}$, and $\mathrm{Cu}$ were studied (Table 1). The effect of TE, which resulted in the highest BMP was also tested individually.

Different concentrations of sodium sulfide (corresponding to $50,75,150,250$, and $500 \mathrm{mg} \mathrm{H}_{2} \mathrm{~S} / \mathrm{L}$ ) were added in the serum bottles to perform the batch experiment on the hydrogen sulfide inhibition of the BMP tests of FW.

\section{Analytical Methods}

Total solids (TS) and volatile solids (VS) were conducted in triplicates according to the standard methods ${ }^{1}$, and the ashes were preserved with $1 \%$ nitric acid. Total TE concentration was analyzed in ash samples by Thermo-Scientific ICP-MS. The minimum detection limit for the ICP-MS method was $2 \mu \mathrm{g} / \mathrm{L}$, and the final values were converted to $\mu \mathrm{g} / \mathrm{gTS}$ for comparison with the literature. Hydrogen sulfide and volatile fatty acids (VFA) samples were taken every 4 days from the liquid fraction. Hydrogen sulfide concentrations were measured with Hach test kits following the manufacturer's guidelines (HACH, Loveland, Colorado, USA). The VFA samples were prepared in $2 \%$ formic acid and analyzed by gas chromatography (Varian 430-GC) equipped with a Nukol Supelco FID column, using helium as a carrier gas as described by Mussoline et al. (2013).

${ }^{1}$ APHA, Standard Methods for the Examination of Water and Wastewater 21st Edn. ISBN: 0875530478.
TABLE 2 | Concentration of TE in the FW and inoculum.

\begin{tabular}{lccc}
\hline & Buffalo manure $(\boldsymbol{\mu} \mathbf{g} / \mathbf{g T S})$ & FW-A $(\boldsymbol{\mu} \mathbf{g} / \mathbf{g T S})$ & FW-B $(\boldsymbol{\mu} \mathbf{g} / \mathbf{g T S})$ \\
\hline $\mathrm{Fe}$ & $682.72 \pm 28.78$ & $213.91 \pm 24.50$ & $510.93 \pm 7.34$ \\
$\mathrm{Ni}$ & $4.93 \pm 0.05$ & $3.97 \pm 1.32$ & $11.25 \pm 0.95$ \\
$\mathrm{Mn}$ & $107.78 \pm 26.88$ & $52.12 \pm 5.10$ & $20.33 \pm 5.86$ \\
$\mathrm{Co}$ & $1.35 \pm 0.45$ & $0.73 \pm 0.07$ & $2.73 \pm 0.08$ \\
$\mathrm{Cu}$ & $28.72 \pm 22.07$ & $3.97 \pm 0.66$ & $22.27 \pm 4.65$ \\
$\mathrm{Zn}$ & $214.42 \pm 137.72$ & $239.07 \pm 33.77$ & $361.34 \pm 4.27$ \\
$\mathrm{Se}$ & $4.81 \pm 0.06$ & $\mathrm{BDL}$ & $1.34 \pm 0.45$ \\
$\mathrm{Mo}$ & $7.32 \pm 2.41$ & $1.99 \pm 0.66$ & $10.67 \pm 5.70$ \\
$\mathrm{~W}$ & $<0.03$ & $\mathrm{~N} / \mathrm{A}$ & $0.43 \pm 0.02$ \\
\hline
\end{tabular}

$B D L$, below detection limit; N/A, not analyzed.

\section{RESULTS}

\section{Characterization of Substrate and Inoculum}

The TS and VS concentrations of the synthetic FW were 24.1 $( \pm 0.4) \%$ and $21.9( \pm 0.1) \%$, respectively, whereas the inoculum contained $2.5( \pm 0.5) \%$ of TS and $1.5( \pm 0.4) \%$ of VS. Table 2 shows the concentrations of the TE in the FW and inoculum. Interestingly FW-B (prepared in USA) had a much higher concentration of all TE, except for manganese $(\mathrm{Mn})$, regardless that the same ingredients were used for the FW preparation. It is also interesting to note that selenium (Se) was not detected in FW-A, but was present at $1.3( \pm 0.5) \mu \mathrm{g} / \mathrm{gTS}$ in FW-B (Table 2).

\section{Effect of TE Concentration on AD of FW-A}

The control (with no TE addition) of FW-A had a net SBP of $421.2( \pm 14.6) \mathrm{mlCH}_{4} / \mathrm{gVS}_{\text {added }}$. Table 3 shows the cocktail solution concentration and its enhancing or inhibiting effects on the net SBP of FW-A. It can be seen that supplementing a TE cocktail solution of $5-500 \mu \mathrm{g} / \mathrm{L}$ to the BMP test bottles yielded an enhancement of the $\mathrm{AD}$ process, while higher concentrations resulted in an inhibition of the AD process (Table $3 \mathbf{A}$ ).

Figure 1 shows the highest SBP results of $499.6( \pm 8.0)$ $\mathrm{mlCH}_{4} / \mathrm{gVS}_{\text {added }}$ and $489.9( \pm 7.3) \quad \mathrm{mlCH}_{4} / \mathrm{gVS}_{\text {added }}$ were achieved with a supplementation of 50 and $10 \mu \mathrm{g} / \mathrm{L}$ of TE cocktails, respectively, which are $18.7( \pm 2.2) \%$ and 16.0 $( \pm 5.8) \%$ higher than the control. Hence, the optimum TE supplementation concentration range is between 10 and $50 \mu \mathrm{g} / \mathrm{L}$ for this particular type of inoculum and FW (Table 3A and Figure 1).

Table 3B shows the concentrations of the individual TE for the second set of experiment. Figure 2 illustrates the highest enhancement was achieved with the second ( $\mathrm{Co}, \mathrm{Ni}, \mathrm{Fe}$ ) and third (Co, Ni, Fe, Zn) cocktail solutions, with a SBP of 481.3 $( \pm 10.1) \mathrm{mlCH}_{4} / \mathrm{gVS}_{\text {added }}$ and $472.4( \pm 8.0) \mathrm{mlCH}_{4} / \mathrm{gVS}_{\text {added }}$, respectively. The increase of SBP by the first and fourth groups of TE was almost similar with negligible differences (459.9 \pm 8.9 and $462.8 \pm 12.4 \mathrm{mlCH}_{4} / \mathrm{gVS}_{\text {added }}$ ), which implies the cobalt, nickel, iron and zinc cocktail had a more positive effect than manganese and copper addition. Hence, the next set of experiments was 
TABLE 3 | Effect of TE concentrations on the net SBP of FW-A: (A) First set of experiment; and (B) Second set of experiment.

\begin{tabular}{lcccccccccc} 
(A) & & & & & & & & \\
Cocktail solution & Concentration & Individual TE $(\mu \mathbf{g} / \mathbf{L})$ & $\mathbf{N i}(\mu \mathbf{M})$ & $\mathbf{C u}(\mu \mathbf{M})$ & $\mathbf{M n}(\mu \mathbf{M})$ & $\mathbf{F e}(\mu \mathbf{M})$ & $\mathbf{C o}(\mu \mathbf{M})$ & $\mathbf{Z n}(\mu \mathbf{M})$ & $\mathbf{S e}(\mu \mathbf{M})$ & $\mathbf{M o}(\mu \mathbf{M})$ \\
\hline C1 & $10 \mathrm{mg} / \mathrm{L}$ & 1250 & 21.29 & 20 & 23 & 22 & 21 & 19 & 16 & 13 \\
C2 & $3 \mathrm{mg} / \mathrm{L}$ & 375 & 6.39 & 5.86 & 6.82 & 6.70 & 6.36 & 5.73 & 4.75 & 3.91 \\
C3 & $1 \mathrm{mg} / \mathrm{L}$ & 125 & 2.13 & 1.95 & 2.27 & 2.23 & 2.12 & 1.91 & 1.58 & 1.30 \\
C4 & $500 \mu \mathrm{g} / \mathrm{L}$ & 62.5 & 1.06 & 0.98 & 1.14 & 1.12 & 1.06 & 0.96 & 0.79 & 0.65 \\
$\mathrm{C5}$ & $100 \mu \mathrm{g} / \mathrm{L}$ & 12.5 & 0.21 & 0.20 & 0.23 & 0.22 & 0.21 & 0.19 & 0.16 & 0.13 \\
C6 & $50 \mu \mathrm{g} / \mathrm{L}$ & 6.25 & 0.11 & 0.10 & 0.11 & 0.11 & 0.11 & 0.10 & 0.08 & 0.07 \\
C7 & $10 \mu \mathrm{g} / \mathrm{L}$ & 1.25 & 0.02 & 0.02 & 0.02 & 0.02 & 0.02 & 0.02 & 0.02 & 0.01 \\
C8 & $5 \mu \mathrm{g} / \mathrm{L}$ & 0.625 & 0.01 & 0.01 & 0.01 & 0.01 & 0.01 & 0.01 & 0.01 & 0.01 \\
\hline
\end{tabular}

(B)

Group number TE in the cocktail solution

Concentrations of individual TE $(\mu \mathrm{M})$

\begin{tabular}{|c|c|c|c|c|c|c|c|c|c|}
\hline & & & & & & & & & \\
\hline & & $\mathrm{Ni}$ & Co & $\mathrm{Fe}$ & $\mathrm{Zn}$ & $\mathrm{Cu}$ & $M n$ & $\mathrm{Se}$ & Mo \\
\hline 1 & $\mathrm{Co} ; \mathrm{Ni}$ & 0.43 & 0.42 & - & - & - & - & - & - \\
\hline 2 & $\mathrm{Co} ; \mathrm{Ni} ; \mathrm{Fe}$ & 0.28 & 0.28 & 0.30 & - & - & - & - & - \\
\hline 4 & $\mathrm{Co} ; \mathrm{Ni} ; \mathrm{Fe} ; \mathrm{Zn} ; \mathrm{Mn} ; \mathrm{Cu}$ & 0.14 & 0.14 & 0.15 & 0.13 & 0.13 & 0.15 & - & - \\
\hline - & Se; Mo & - & - & - & - & - & - & 0.32 & 0.26 \\
\hline
\end{tabular}

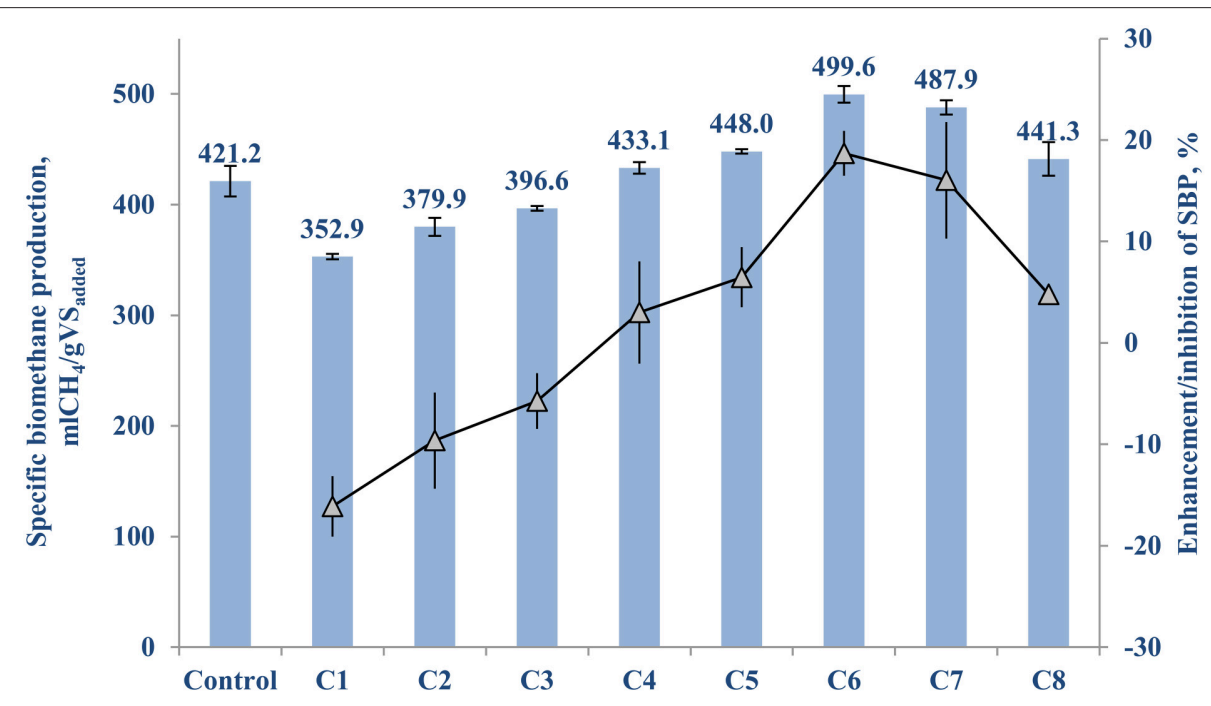

FIGURE 1 | Effect of TE cocktail concentration $(5 \mu \mathrm{g} / \mathrm{L}-10 \mathrm{mg} / \mathrm{L})$ on the SBP of FW-A.

carried out to determine the individual effect of this third group of TE on the BMP of FW, i.e., Co (II), Ni (II), Fe (II), and Zn (II).

Figure $3 \mathrm{~A}$ shows the cumulative biomethane production curves of the BMP bottles supplied with $50 \mu \mathrm{g} / \mathrm{L}$ solutions of Fe $(0.89 \mu \mathrm{M}), \mathrm{Zn}(0.76 \mu \mathrm{M}), \mathrm{Ni}(0.85 \mu \mathrm{M})$, and Co $(0.85 \mu \mathrm{M})$ each. Each of them yielded at least a $18 \%$ higher biomethane production than the control. Figure 3B shows the Fe (II) supplementation yielded a remarkable $39.2( \pm 0.6) \%$ higher SBP, followed by nickel and cobalt with a $23-26 \%$ increase.

Another set of experiments was carried out supplementing TE with oxidation state of six, i.e., transition metals [Mo (VI)] or metalloid [Se (VI)] as a cocktail (Table 1) as well as individually (Figure 4). Adding only Se (VI) to the bottles yielded a notable SBP increase of 34.1 ( \pm 5.6$) \%$ (Figure 4B), whereas Mo (VI) had an inhibitory effect (data not presented). Supplementing a cocktail of TE (VI) had a relatively poor SBP increase of 9.5 $( \pm 1.3) \%$, which can be attributed mostly to the Se (VI) effect.

Se (VI) and Fe (II) supplementation resulted in the highest (>30\%) enhancement of the BMP of FW-A (Figures 3, 4), thus the detailed VFA analysis of these samples was studied. Figure 5 shows the samples with the Fe (II) and Se (VI) supplementation had much lower acetic, propionic, iso-butyric and butyric acids 


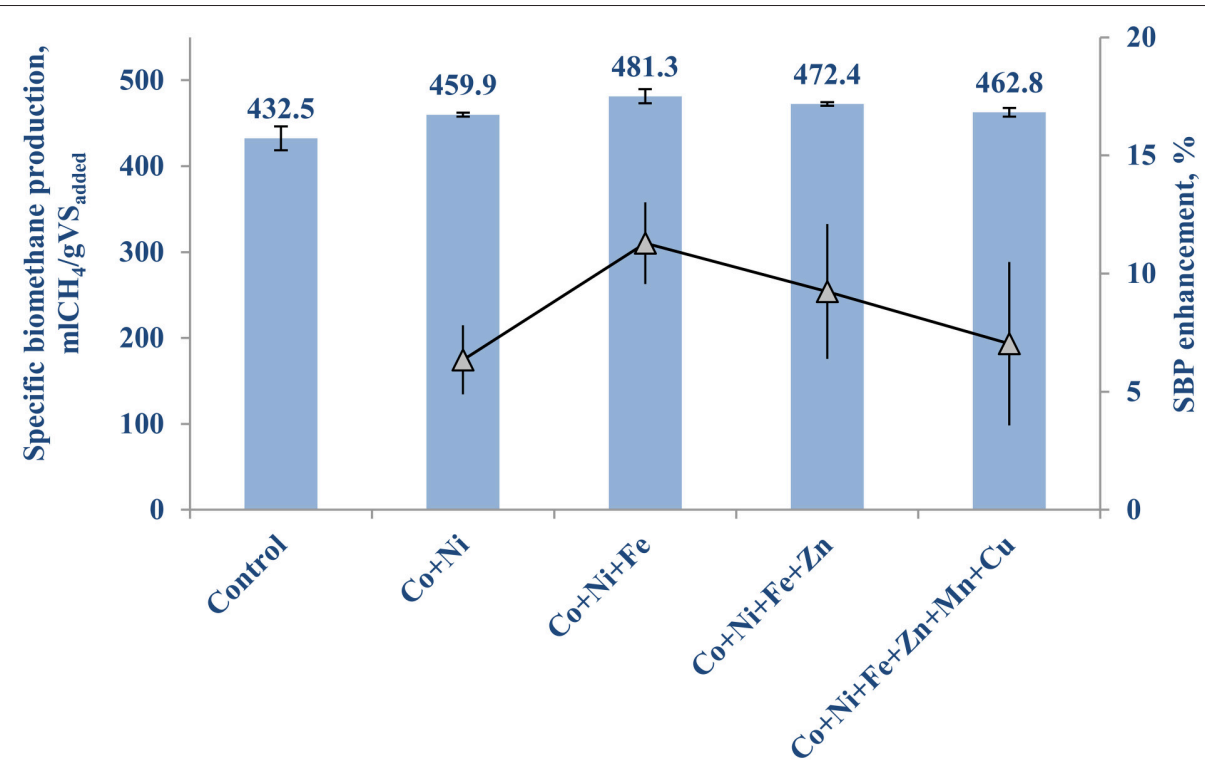

FIGURE 2 | Effect of TE (II) on the SBP of FW-A.

concentrations as compared to the control. On the first day of the BMP test, both iron, and selenium supplemented bottles had a similar (442.9 and $465.1 \mathrm{mg} / \mathrm{L}$ ) acetic acid concentration, which is twice as less as the concentration in the control $(893.2 \mathrm{mg} / \mathrm{L})$. On day 5 , the acetic acid concentration decreased to $148.7 \mathrm{mg} / \mathrm{L}$ in the BMP test with iron supplementation, whereas it increased to $562.7 \mathrm{mg} / \mathrm{L}$ in the bottle with selenium supplementation. The acetic acid concentration gradually decreased in all the BMP test bottles with time (Figure 5). The propionic acid concentration in the control was higher $(279.3 \mathrm{mg} / \mathrm{L})$ as compared to the propionic acid concentration in the iron $(173.5 \mathrm{mg} / \mathrm{L})$ and selenium $(112.1 \mathrm{mg} / \mathrm{L})$ supplemented bottles. It should also be stressed that throughout the experiment the propionic acid concentration was much lower in the selenium supplemented incubations.

\section{Effect of TE Supplementation on FW-B}

The net SBP of the FW-B was $412.5( \pm 12.0) \mathrm{mlCH}_{4} / \mathrm{gVS}_{\text {added }}$, which is comparable with the SBP obtained with FW in EU. Surprisingly, supplementation of TE did not yield any enhancement of the biomethane production (data not presented). Only the case of Se (VI) addition of $10-20 \mu \mathrm{g} / \mathrm{L}$ $(0.13-0.25 \mu \mathrm{M})$ yielded a $30.1( \pm 2.4) \%$ increase of biomethane production (Figure 6).

\section{Hydrogen Sulfide Inhibition on FW-B}

Figure 7 shows the sulfide inhibition of the AD of FW-B starts around $50 \mathrm{mg} / \mathrm{L}$, resulting in $5.13( \pm 2.76) \%$ less SBP. Based on the SBP results and the hydrogen sulfide concentrations, the $\mathrm{IC}_{50}$ was calculated as $215 \mathrm{mg} / \mathrm{L}$ at $\mathrm{pH}$ of $6.4-8.0$. The maximal hydrogen sulfide concentration obtained in all the tested scenarios with TE as well as the control for FW-B, was less than $15 \mathrm{mg} / \mathrm{L}$ in the system throughout the experiment.

\section{DISCUSSION}

\section{Importance of TE Supplementation on AD of FW}

This study showed that the background TE concentration of FW determines the enhancement of the BMP of FW (Table 4). The net SBP of FW-A and FW-B were $421.2( \pm 14.6) \mathrm{mlCH}_{4} / \mathrm{gVS}_{\text {added }}$ and $412.5( \pm 12.0) \mathrm{mlCH}_{4} / \mathrm{gVS}_{\text {added }}$, respectively, which is in a good agreement with the literature (Banks et al., 2012; De Vrieze et al., 2013; Ariunbaatar et al., 2014, 2015). The effect of TE addition had nevertheless a different effect on FW-A and FW-B, due to their different TE background concentration (Table 2).

The importance of the trace metals $\mathrm{Fe}, \mathrm{Ni}$, Co and the metalloid Se was very clear for FW-A with low TE concentration, while only Se addition had enhancing effect on FW-B with high TE background concentration (Table 4). Similarly Lindorfer et al. (2012) reported that samples from exclusive digestion of FW and food production wastes from single sources in Germany and Austria showed a low concentration of several TE, including $\mathrm{Cu}$, $\mathrm{Ni}, \mathrm{Zn}, \mathrm{Co}, \mathrm{Mn}, \mathrm{Mo}$, Se, and W.

Hydrogen sulfide, produced by degradation of sulfur containing amino acids or dissimilarity sulfate reduction using sulfate present in the initial substrate, is highly toxic to microorganisms, as it forms an inactive protein, metal complexation, and interferes with key metabolic enzymes in the cells (Karhadkar et al., 1987; Zandvoort et al., 2006; Chen et al., 2014). Therefore, the experiment on sulfide inhibition was conducted (Figure 7) and the calculated $\mathrm{IC}_{50}$ was in the range of the reported values of $125-250 \mathrm{mg} / \mathrm{L}$ (Koster et al., 1986; Oleszkiewicz et al., 1989; Chen et al., 2008). However, no difference in the hydrogen sulfide concentration was observed between the control and the TE supplemented incubations $(50 \mu \mathrm{g} / \mathrm{L})$. The hydrogen sulfide concentrations $(15 \mathrm{mg} / \mathrm{L})$ that 

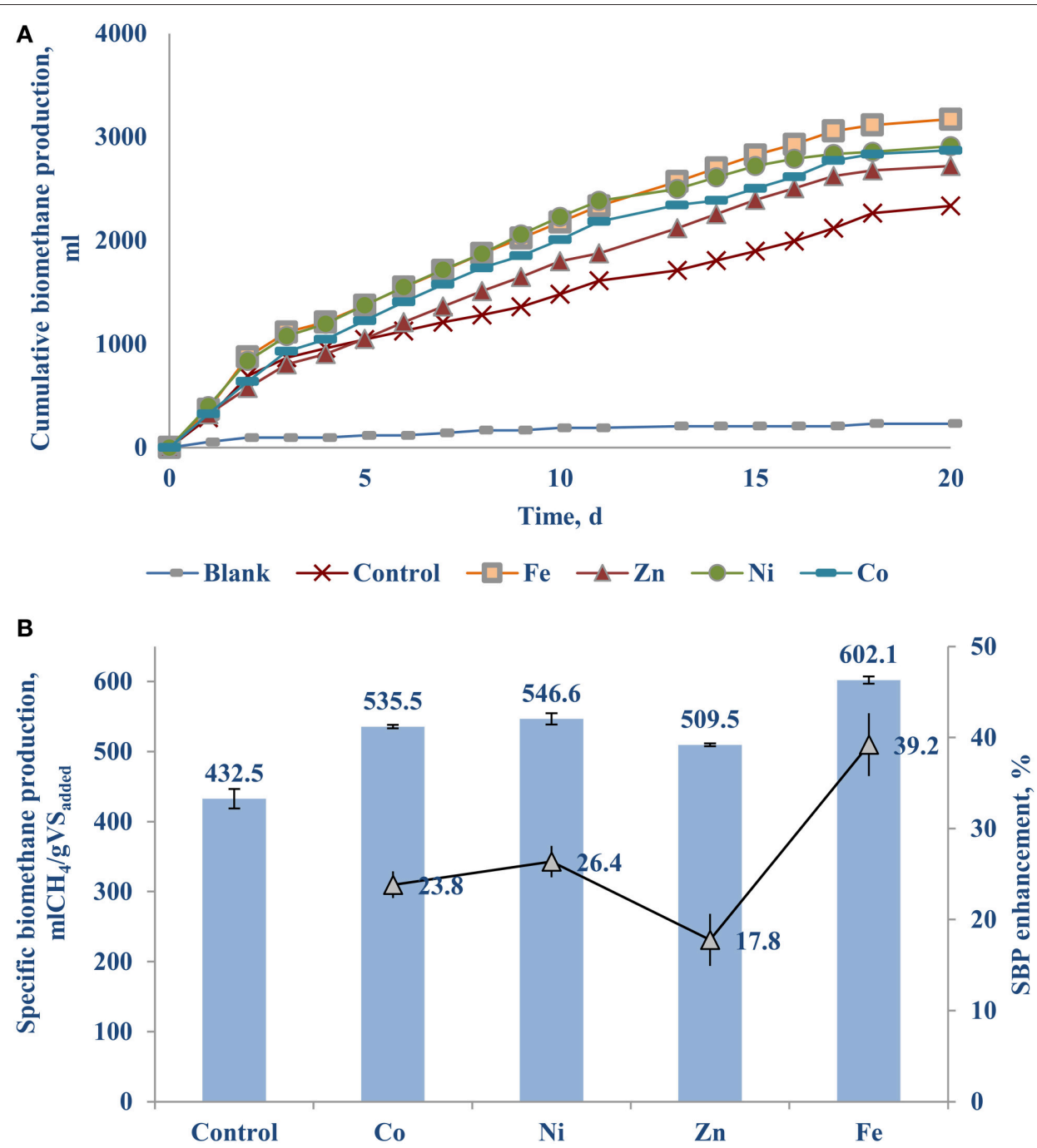

FIGURE 3 | The individual effect of $\mathrm{Fe}, \mathrm{Zn}, \mathrm{Ni}$, and $\mathrm{Co}$ on the BMP of FW-A: (A) Cumulative methane curves; and (B) SBP.

developed in the BMP tests were much lower than the inhibitory level (Figure 7) throughout the experiment, suggesting that there was no hydrogen sulfide inhibition in the AD of FW. Ortner et al. (2014) also observed no sulfide inhibition with AD treating slaughterhouse waste. Hence, the enhanced SBP due to addition of TE was not related with sulfide, but rather with the enzymatic reactions (physiological contribution; Oleszkiewicz and Sharma, 1990; Glass and Orphan, 2012; Thanh et al., 2015) and/or the aggregation of microbial biomass promoting interspecies electron transfer (Oleszkiewicz and Sharma, 1990; Thanh et al., 2015).

\section{Roles of Fe (II) and Se (VI) on the AD of FW}

This study elucidated the most important TE (II) were $\mathrm{Fe}>\mathrm{Ni}>$ Co for the AD of FW-A (Figures 2, 3). It corresponds with the order of the most commonly found TE concentrations $(\mathrm{Fe}>>$ $\mathrm{Zn} \geq \mathrm{Ni}>\mathrm{Co}=\mathrm{Mo}>\mathrm{Cu}$ ) in methanogenic archaea (Takashima and Speece, 1989). The performance of the AD process fed with
FW can indeed be enhanced by supplementing Fe (II) (Qiang et al., 2012, 2013; De Vrieze et al., 2013).

Regardless of the biochemical pathways to produce methane, almost every metalloenzyme involved in the methanogenesis contains Fe (Glass and Orphan, 2012), whereas Co and $\mathrm{Ni}$ are contained only in some of the essential metalloenzymes such as CO dehydrogenase, acetyl-CoA decarbonylase, methylH4SPT:HS-CoM methyl-transferase, methyl-CoM reductase (Oleszkiewicz and Sharma, 1990; Zandvoort et al., 2006; Pobeheim et al., 2011; Glass and Orphan, 2012; Nordell et al., 2016). Besides, the crucial roles of $\mathrm{Fe}$ in metalloenzymes, high concentrations of Fe supplementation are an important factor for other TE speciation and solubility, particularly for $\mathrm{Ni}$ and Co (Shakeri Yekta et al., 2014). Therefore, supplementing $\mathrm{Fe}(0.89 \mu \mathrm{M}$ for $\mathrm{FW}-\mathrm{A})$ resulted in the stimulation of the overall microbial activities and thus a quick consumption of VFA (Figure 5) and an increased SBP (Figure 3). Nevertheless, addition of Fe for FW-B 

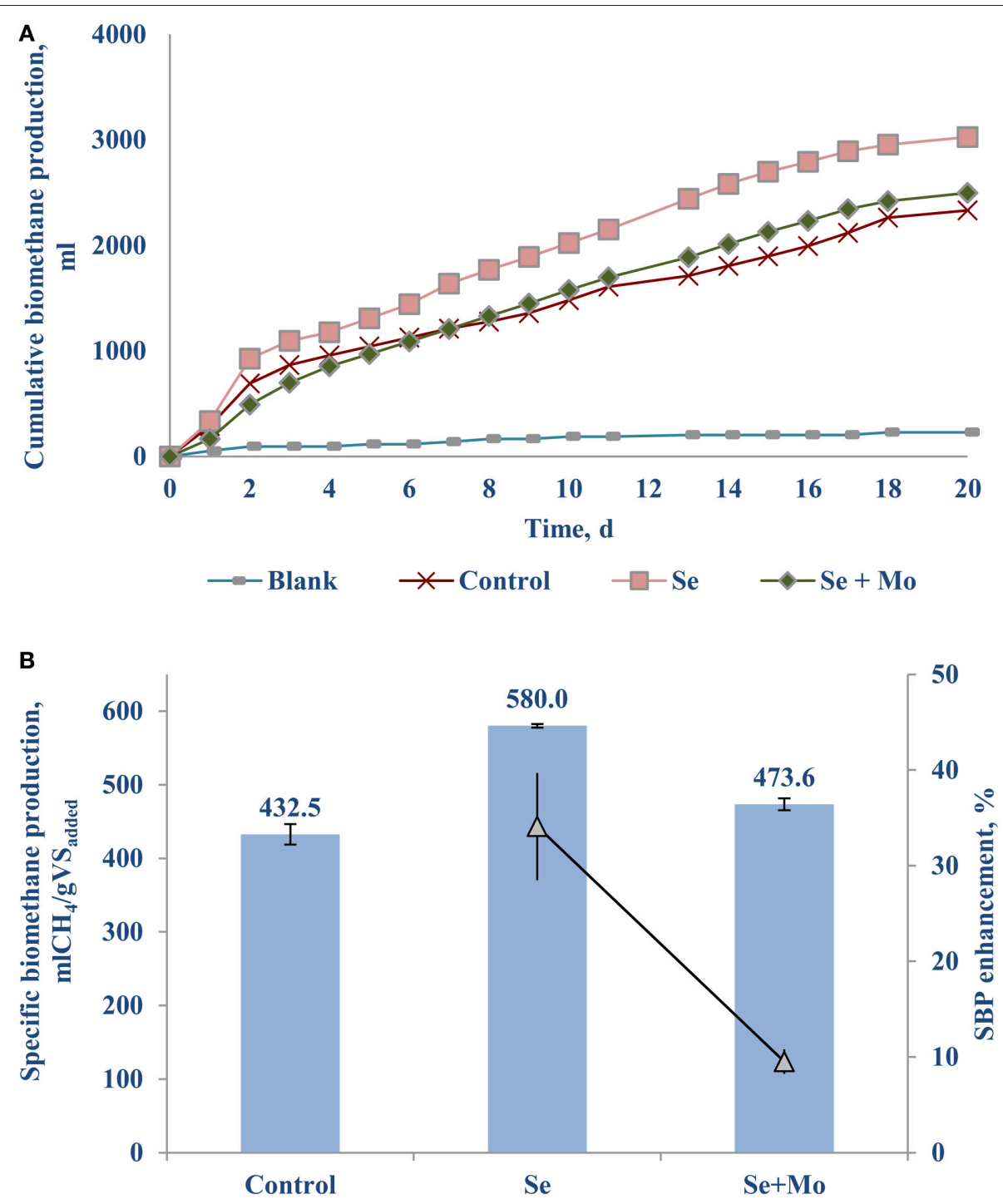

FIGURE 4 | Effect of TE (VI) on the SBP of FW-A: (A) Cumulative methane curves; and (B) SBP.

did not result in enhancement or inhibition of the $\mathrm{AD}$ process. Interestingly, the total concentration of $\mathrm{Fe}$ in $\mathrm{FW}-\mathrm{B}$ (Table 1) is almost similar to the inhibitory level of the FW-A (Table 3), which indicates only some of the Fe in FW-B was bioavailable.

Selenium was not detected in FW-A, and was present only in low concentrations in FW-B (Table 1). This study showed that $\mathrm{Se}$ (VI) of the AD of FW is as important as Fe (II) for the $\mathrm{AD}$ of FW. The crucial roles of Se (VI) have been stressed by several recent studies (Banks et al., 2012; Facchin et al., 2013; Yirong et al., 2015; Zhang et al., 2015). Supplementing Se (VI) reduced both the acetic and propionic acid concentrations in the batch incubation, thus enhancing the biomethane production by more than 30\% (Figures 4-6). It indicates that $\mathrm{Se}$ is involved in common hydrogenases (Oleszkiewicz and Sharma, 1990), provides co-enzymes necessary for propionate oxidation and syntrophic hydrogenotrophic methanogenesis (Banks et al., 2012; Yirong et al., 2015). Besides, selenocysteine (Sec) has been recognized as the 21st amino acid, and a constituent of at least 25 proteins, named selenoproteins, present in all living systems from Archaea, Bacteria, and Eukarya (Nancharaiah and Lens, 2015). Thus, lack of Se can slow down the AD process. The biochemical role of Se in stimulating AD of FW should be further studied using expression of the hydrogenases as a function of TE concentration as done by Worm et al. (2009).

The optimal Se concentration for $\mathrm{AD}$ of $\mathrm{FW}$ was determined in the range of $25-50 \mu \mathrm{g} / \mathrm{L}(0.32-0.64 \mu \mathrm{M})$. Se was not detected in FW-A, whereas it was $1.34( \pm 0.45) \mu \mathrm{g} / \mathrm{gTS}$ in FW-B. Thus, less Se supplementation was required for the AD of FW-B to achieve the same enhancement of the biomethane production (Tables $\mathbf{1}$, 4, Figures 4, 6). This indicates the lack of Se in local food can 

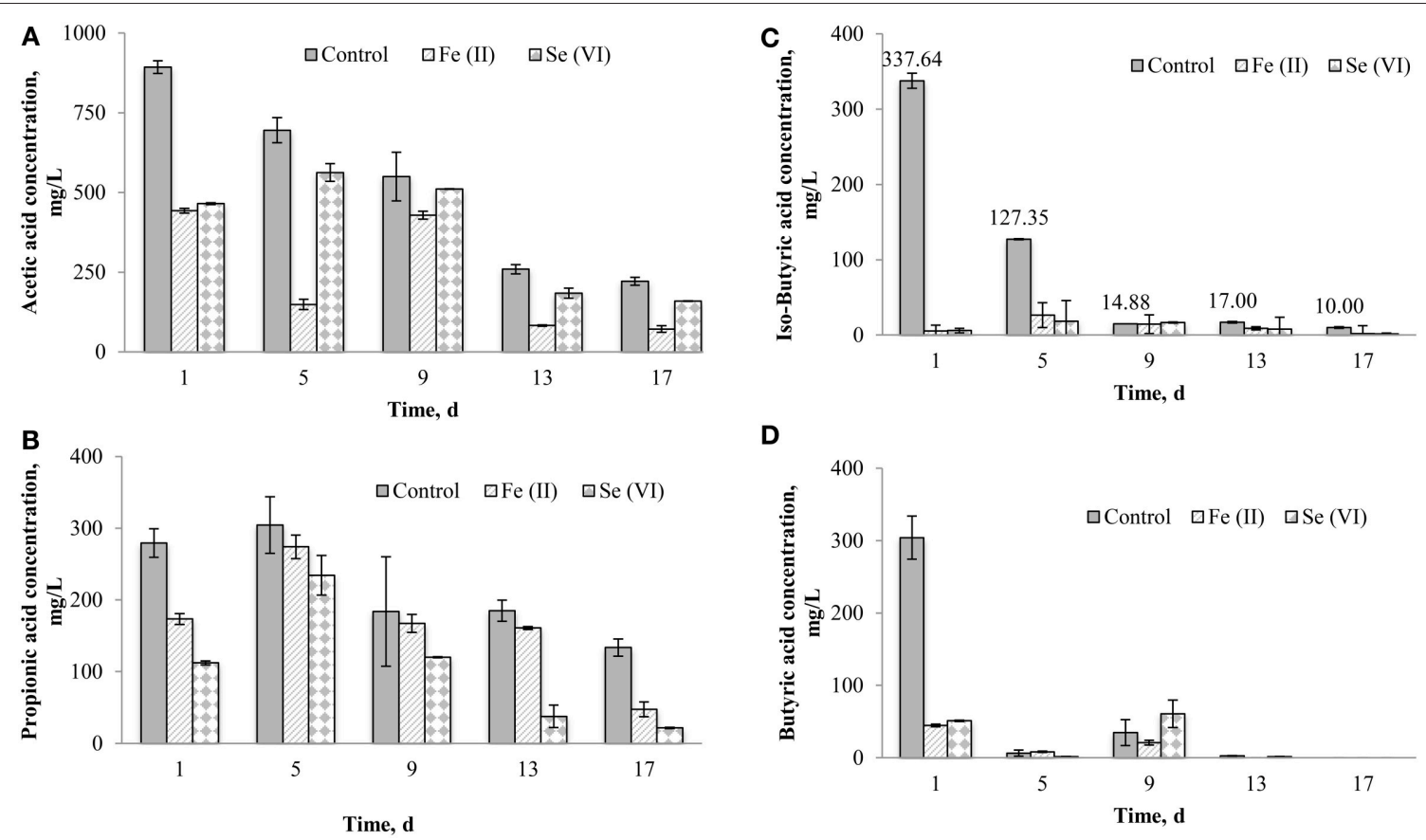

FIGURE 5 | Effect of Se (VI) and Fe (II) supplementation on the VFA production during the AD of FW-A: (A) Acetic acid; (B) Propionic acid; (C) Iso-butyric acid; and (D) Butyric acid.

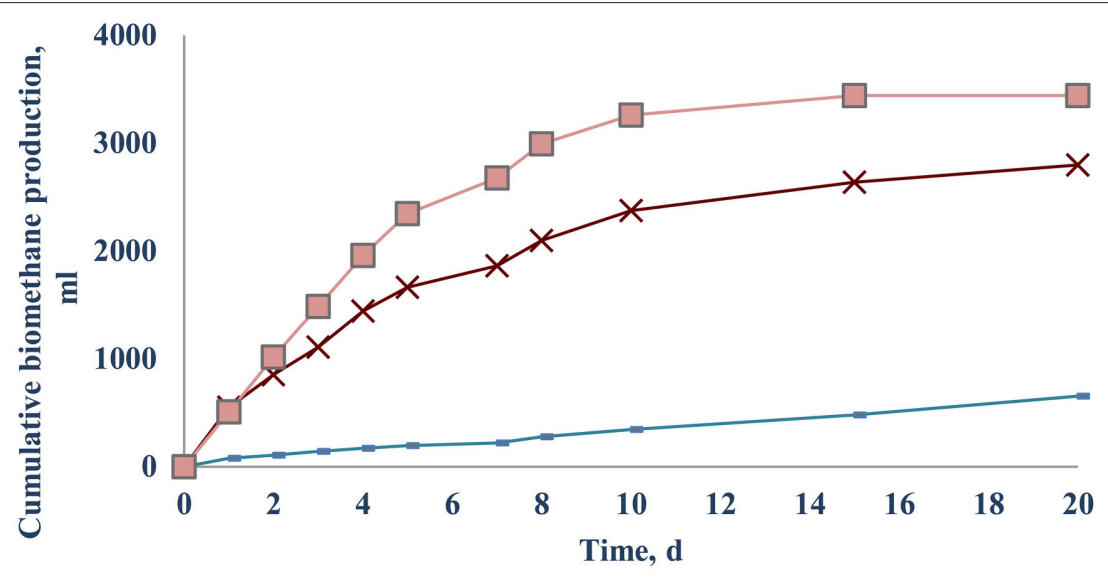

$\simeq$ Blank $\rightarrow$ Control $\square-$ Se added

FIGURE 6 | Effect of Se (VI) addition on FW-B.

result in poor or deteriorated $\mathrm{AD}$. It could be attributed to the Se bioavailability in agricultural soils to bio-uptake by plants and organisms, which dictates the entrance of Se in terrestrial Se food chain (Winkel et al., 2011), and Se fertilization might be needed.

Even though TE speciation and bioavailability was not studied, this research showed their important implication. Bioavailability depends on physical, biological, and chemical factors that are highly complex and interdependent processes (Worms et al.,
2006; Glass and Orphan, 2012). For instance, sometimes even if TE are taken up in the cell, their effects may be reduced by complexation inside the cytosol, compartmentalization, and efflux or by modification of the extracellular TE speciation (Worms et al., 2006; Glass and Orphan, 2012). In general, TE transport across the cell membrane is rate limiting and the overall process can be simplified to a thermodynamic equilibrium among the TE species. Further laboratory as well as mathematical modeling research is required on TE speciation and TE effects on 


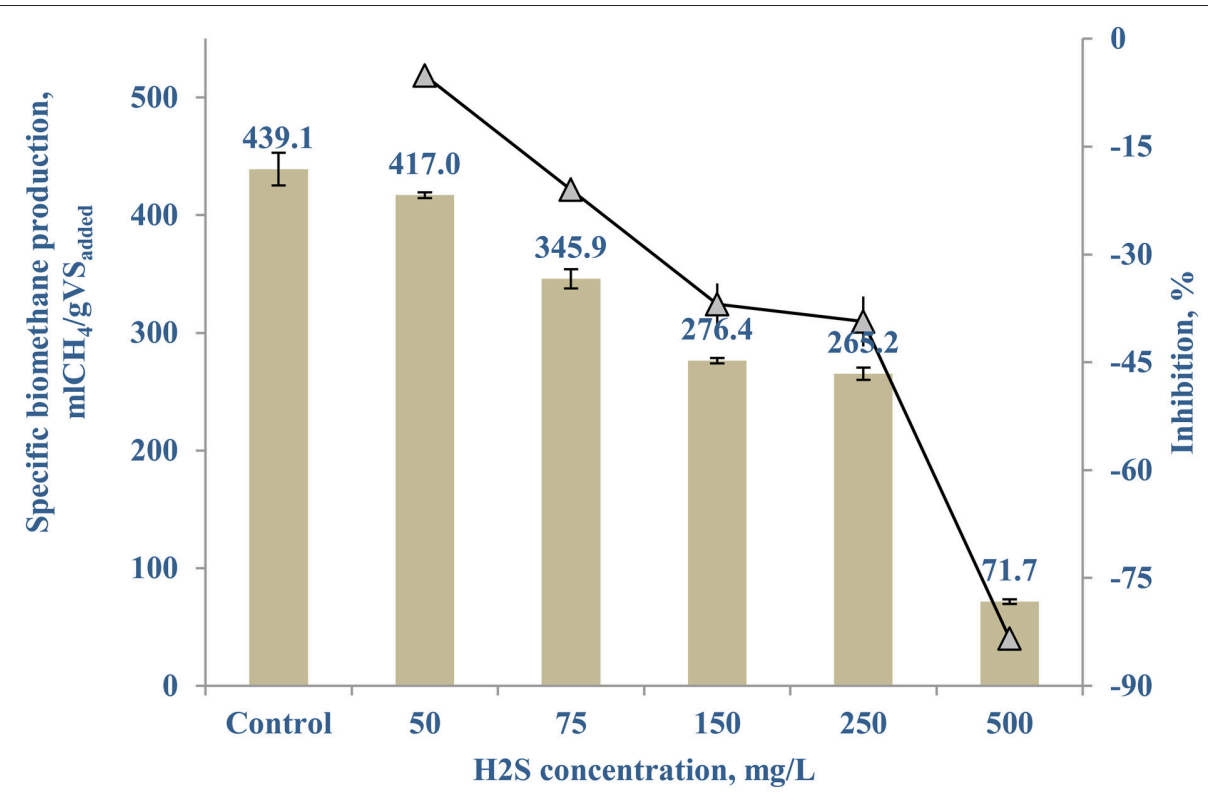

FIGURE 7 | Effect of hydrogen sulfide toxicity on AD of FW-B.

TABLE 4 | Enhanced AD of FW by supplementing TE.

\begin{tabular}{|c|c|c|c|}
\hline TE Concentrations & Experimental conditions & Enhanced AD process & References \\
\hline $\mathrm{Fe}(50 \mu \mathrm{g} / \mathrm{L}=0.8 \mu \mathrm{M})$ & Mesophilic $\left(35 \pm 2^{\circ} \mathrm{C}\right)$ batch & $\begin{array}{l}\text { 39\% higher biomethane production from } \\
\text { FW-A, while no effect on FW-B }\end{array}$ & This study \\
\hline $\begin{array}{l}\text { Se }(25-50 \mu \mathrm{g} / \mathrm{L}=0.32-0.64 \mu \mathrm{M} \\
\text { depending on the initial concentration in } \\
\text { the FW) }\end{array}$ & Mesophilic $\left(35 \pm 2^{\circ} \mathrm{C}\right)$ batch & $\begin{array}{l}30-35 \% \text { higher biomethane production } \\
\text { from both FW-A and FW-B }\end{array}$ & This study \\
\hline $\begin{array}{l}\text { Cocktail of Se }(0.2 \mathrm{mg} / \mathrm{L}), \mathrm{Fe}(5 \mathrm{mg} / \mathrm{L}) \text {, } \\
\text { Co }(1 \mathrm{mg} / \mathrm{L}) \text { and } \mathrm{Ni}(1 \mathrm{mg} / \mathrm{L})\end{array}$ & Mesophilic $\left(35^{\circ} \mathrm{C}\right)$ continuous (OLR = 1-4 gVS/L.d) & $\begin{array}{l}\text { Recovered from VFA accumulation at } 5 \\
\text { gVS/L.d }\end{array}$ & Zhang et al., 2015 \\
\hline $\begin{array}{l}\text { Cocktail containing } 0.1 \mathrm{mg} / \mathrm{L} \text { of } \mathrm{Al}, \mathrm{B} \text {, } \\
\mathrm{Co}, \mathrm{Cu}, \mathrm{Fe}, \mathrm{Mn}, \mathrm{Ni}, \mathrm{Zn}, \mathrm{Mo} \text {, Se, and W }\end{array}$ & $\begin{array}{l}\text { Thermophilic }\left(55^{\circ} \mathrm{C}\right) \text { continuous }(\mathrm{OLR}=1-4 \\
\text { gVS/L.d) }\end{array}$ & Delayed VFA accumulation by 88 days & Yirong et al., 2015 \\
\hline $\begin{array}{l}\text { Cocktail of Se }(0.16 \mu \mathrm{g} / \mathrm{g}) \text { and Co } \\
(0.22 \mu \mathrm{g} / \mathrm{g})\end{array}$ & $\begin{array}{l}\text { Mesophilic }\left(36-37^{\circ} \mathrm{C}\right) \text { semi-continuous (OLR = } \\
1.6-5 \mathrm{gVS} / \mathrm{L} . \mathrm{d})\end{array}$ & $\begin{array}{l}\text { Organic loading could be increased from } 2 \\
\text { gVS/L.d to } 5 \text { gVS/L.d with no ammonia } \\
\text { inhibition }\end{array}$ & Banks et al., 2012 \\
\hline \multirow[t]{2}{*}{ Cocktail containing $1 \mathrm{mg} / \mathrm{L} \mathrm{Co}, \mathrm{Ni}$, Fe } & Mesophilic continuous (OLR = 1.9-6.3 gCOD/L.d) & $\begin{array}{l}\text { Delayed digester failure due to VFA } \\
\text { accumulation }\end{array}$ & Qiang et al., 2012 \\
\hline & Mesophilic batch & $\begin{array}{l}7.5-7.8 \text { times faster fermentation process } \\
\text { as compared to control }\end{array}$ & \\
\hline $\begin{array}{l}\text { Cocktail of Se (1.8 mg/L), W (0.8 mg/L) } \\
\text { and Co }(0.06 \mathrm{mg} / \mathrm{L})\end{array}$ & $\begin{array}{l}\text { Mesophilic }\left(37^{\circ} \mathrm{C}\right) \text { continuous }(\mathrm{OLR}=2.5-3 \\
\text { gVS/L.d) }\end{array}$ & $7-15 \%$ increase of biomethane production & Feng et al., 2010 \\
\hline
\end{tabular}

the $\mathrm{AD}$ process and how to use this to implement process control of TE supplementation.

\section{CONCLUSIONS}

The supplementation of trace elements increased the biomethane potential of a FW with low trace elements concentration: the most effective elements were Fe with an increase of $39.2( \pm 0.6) \%$ of biomethane production of the FW from Europe, followed by Se $(34.1 \pm 5.6 \%$ increase), $\mathrm{Ni}$ (26.4 $\pm 0.2 \%$ increase), and Co $(23.8 \pm 0.2 \%$ increase). The same experiments did not result in an increased biomethane production when FW with an elevated background concentration of trace elements was used, except for Se supplementation. Addition of $10 \mu \mathrm{g} / \mathrm{L}$ Se $(0.13 \mu \mathrm{M})$ to the incubation of FW with background concentration (making the total Se 
concentration $\sim 50 \mu \mathrm{g} / \mathrm{L}=0.63 \mu \mathrm{M}$ ) resulted in a $30 \%$ increased biomethane production. Sulfide inhibition was not observed at the prevailing concentrations, and hence the enhancing effect of trace elements is at the enzymatic or biomass stimulating level.

\section{AUTHOR CONTRIBUTIONS}

JA is the corresponding author and main researcher. GE is project leader and main supervisor. DY is the project collaborating partner and co-supervisor. PL is the project initiator and

\section{REFERENCES}

Ariunbaatar, J., Panico, A., Frunzo, L., Esposito, G., Lens, P. N., and Pirozzi, F. (2014). Enhanced anaerobic digestion of food waste by thermal and ozonation pretreatment methods. Environ. Manage. 146, 142-149. doi: 10.1016/j.jenvman.2014.07.042

Ariunbaatar, J., Panico, A., Yeh, D. H., Pirozzi, F., Lens, P. N., and Esposito, G. (2015). Enhanced mesophilic anaerobic digestion of food waste by thermal pretreatment: Substrate versus digestate heating. Waste Manag. 46, 176-181. doi: 10.1016/j.wasman.2015.07.045

Banks, C. J., Zhang, Y., Jiang, Y., and Heaven, S. (2012). Trace element requirements for stable food waste digestion at elevated ammonia concentrations. Bioresource Technol. 104, 127-135. doi: 10.1016/j.biortech.2011.10.068

Chen, Y., Cheng, J. J., and Creamer, K. S. (2008). Inhibition of anaerobic digestion process: a review. Bioresource Technol. 99, 4044-4064. doi: 10.1016/j.biortech.2007.01.057

Chen, J. L., Ortiz, R., Steele, T. W., and Stuckey, D. C. (2014). Toxicants inhibiting anaerobic digestion: a review. Biotechnol. Adv. 32, 1523-1534. doi: 10.1016/j.biotechadv.2014.10.005

Demirel, B., and Scherer, P. (2011). Trace element requirements of agricultural biogas digesters during biological conversion of renewable biomass to methane. Biomass Bioenerg. 35, 992-998. doi: 10.1016/j.biombioe.2010.12.022

De Vrieze, J., De Lathouwer, L., Verstraete, W., and Boon, N. (2013). High-rate iron-rich activated sludge as stabilizing agent for the anaerobic digestion of kitchen waste. Water Res. 47, 3732-3741. doi: 10.1016/j.watres.2013.04.020

Facchin, V., Cavinato, C., Fatone, F., Pavan, P., Cecchi, F., and Bolzonella, D. (2013). Effect of trace element supplementation on the mesophilic anaerobic digestion of food waste in batch trials: the influence of inoculum origin. Biochem. Eng. J. 70, 71-77. doi: 10.1016/j.bej.2012.10.004

FAO (2011). Global Food Losses and Food Waste Study Conducted for the International Congress. Rome.

Feng, X. M., Karlsson, A., Svensson, B. H., and Bertilsson, S. (2010). Impact of trace element addition on biogas production from food industrial waste-linking process to microbial communities. FEMS Microbiol. Ecol. 74, 226-240. doi: 10.1111/j.1574-6941.2010.00932.x

Glass, J. B., and Orphan, V. J. (2012). Trace metal requirements for microbial enzymes involved in the production and consumption of methane and nitrous oxide. Front. Microbiol. 3:61. doi: 10.3389/fmicb.2012.00061

Karhadkar, P. P., Audic, J. M., Faup, G. M., and Khanna, P. (1987). Sulfide and sulfate inhibition of methanogenesis. Water Res. 21, 1061-1066. doi: 10.1016/0043-1354(87)90027-3

Koster, I. W., Rinzema, A., De Vegt, A. L., and Lettinga, G. (1986). Sulfide inhibition of the methanogenic activity of granular sludge at various pH-levels. Water Res. 20, 1561-1567. doi: 10.1016/0043-1354(86) 90121-1

Lindorfer, H., Ramhold, D., and Frauz, B. (2012). Nutrient and trace element supply in anaerobic digestion plants and effect of trace element application. Water Sci. Technol. 66, 1923-1929. doi: 10.2166/wst.2012.399

Liotta, F., Esposito, G., Fabbricino, M., van Hullebusch, E. D., Lens, P. N., Pirozzi, F., et al. (2015). Methane and VFA production in anaerobic digestion of rice co-supervisor. GE, DY and PL have all contributed in finalizing the manuscript.

\section{ACKNOWLEDGMENTS}

This research was supported by the Erasmus Mundus Joint Doctoral Program ETeCoS ${ }^{3}$ (Environmental Technologies for Contaminated Solids, Soils and Sediments) [EU grant agreement FPA no. 2010-0009]; and the Partnerships for International Research and Education (PIRE) project 298 [National Science Foundation (USA) under Grant Number 1243510]. straw under dry, semi-dry and wet conditions during start-up phase. Environ. Technol. doi: 10.1080/09593330.2015.1074288. [Epub ahead of print].

Mussoline, W., Esposito, G., Lens, P., Spagni, A., and Giordano, A. (2013). Enhanced methane production from rice straw co-digested with anaerobic sludge from pulp and paper mill treatment process. Bioresource Technol. 148, 135-143. doi: 10.1016/j.biortech.2013.08.107

Nancharaiah, Y. V., and Lens, P. N. (2015). Selenium biomineralization for biotechnological applications. Trends Biotechnol. 33, 323-330. doi: 10.1016/j.tibtech.2015.03.004

Nordell, E., Nilsson, B., Påledal, S. N., Karisalmi, K., and Moestedt, J. (2016) Co-digestion of manure and industrial waste-The effects of trace element addition. Waste Manag. 47, 21-27. doi: 10.1016/j.wasman.2015.02.032

Oleszkiewicz, J. A., and Sharma, V. K. (1990). Stimulation and inhibition of anaerobic processes by heavy metals-a review. Biol Waste 31, 45-67. doi: 10.1016/0269-7483(90)90043-r

Oleszkiewicz, J. A., Marstaller, T., and McCartney, D. M. (1989). Effects of pH on sulfide toxicity to anaerobic processes. Environ. Technol. 10, 815-822. doi: 10.1080/09593338909384801

Ortner, M., Rameder, M., Rachbauer, L., Bochmann, G., and Fuchs, W. (2015). Bioavailability of essential trace elements and their impact on anaerobic digestion of slaughterhouse waste. Biochem. Eng. J. 99, 107-113. doi: 10.1016/j.bej.2015.03.021

Ortner, M., Leitzinger, K., Skupien, S., Bochmann, G., and Fuchs, W. (2014). Efficient anaerobic mono-digestion of $\mathrm{N}$-rich slaughterhouse waste: influence of ammonia, temperature and trace elements. Bioresource Technol. 174, 222-232. doi: 10.1016/j.biortech.2014.10.023

Parfit, J., Bartherl, M., and Macnaughton, S. (2010). Food waste within food supply chains: quantification and potential for change to 2050. Philos. Trans. R. Soc. Lond. B. Biol. Sci. 365, 3065-3081. doi: 10.1098/rstb.2010.0126

Pobeheim, H., Munk, B., Lindorfer, H., and Guebitz, G. M. (2011). Impact of nickel and cobalt on biogas production and process stability during semi-continuous anaerobic fermentation of a model substrate for maize silage. Water Res. 45, 781-787. doi: 10.1016/j.watres.2010.09.001

Qiang, H., Lang, D. L., and Li, Y. Y. (2012). High-solid mesophilic methane fermentation of food waste with an emphasis on Iron, Cobalt, and Nickel requirements. Bioresource Technol. 103, 21-27. doi: 10.1016/j.biortech.2011.09.036

Qiang, H., Niu, Q., Chi, Y., and Li, Y. (2013). Trace metals requirements for continuous thermophilic methane fermentation of high-solid food waste. Chem. Eng. J. 222, 330-336. doi: 10.1016/j.cej.2013.02.076

Shakeri Yekta, S., Lindmark, A., Skyllberg, U., Danielsson, Å., and Svensson, B. H. (2014). Importance of reduced sulfur for the equilibrium chemistry and kinetics of $\mathrm{Fe}$ (II), Co (II) and Ni (II) supplemented to semi-continuous stirred tank biogas reactors fed with stillage. J. Hazard. Mater. 269, 83-88. doi: 10.1016/j.jhazmat.2014.01.051

Takashima, M., and Speece, R. E. (1989). Mineral nutrient requirements for highrate methane fermentation of acetate at low SRT. Water Pollut. Control Fed. 61, $1645-1650$.

Thanh, P. M., Ketheesan, B., Yan, Z., and Stuckey, D. (2015). Trace metal speciation and bioavailability in anaerobic digestion: a review. Biotechnol. Adv. doi: 10.1016/j.biotechadv.2015.12.006. [Epub ahead of print]. 
Winkel, L. H., Johnson, C. A., Lenz, M., Grundl, T., Leupin, O. X., Amini, M., et al. (2011). Environmental selenium research: from microscopic processes to global understanding. Environ. Sci. Technol. 46, 571-579. doi: 10.1021/es203434d

Worms, I., Simon, D. F., Hassler, C. S., and Wilkinson, K. J. (2006). Bioavailability of trace metals to aquatic microorganisms: importance of chemical, biological and physical processes on biouptake. Biochimie 88, 1721-1731. doi: 10.1016/j.biochi.2006.09.008

Worm, P., Fermoso, F. G., Lens, P. N., and Plugge, C. M. (2009). Decreased activity of a propionate degrading community in a UASB reactor fed with synthetic medium without molybdenum, tungsten and selenium. Enzyme. Microb. Tech. 45, 139-145. doi: 10.1016/j.enzmictec.2009.02.001

Yirong, C., Heaven, S., and Banks, C. J. (2015). Effect of a trace element addition strategy on volatile fatty acid accumulation in thermophilic anaerobic digestion of food waste. Waste Biomass Valorizat. 6, 1-12. doi: 10.1007/s12649-0149327-2

Zandvoort, M. H., van Hullebusch, E. D., Gieteling, J., and Lens, P. N. (2006). Granular sludge in full-scale anaerobic bioreactors: trace element content and deficiencies. Enzyme. Microb. Tech. 39, 337-346. doi: 10.1016/j.enzmictec.2006.03.034
Zhang, L., Lee, Y. W., and Jahng, D. (2011). Anaerobic co-digestion of food waste and piggery wastewater: focusing on the role of trace elements. Bioresource Technol. 102, 5048-5059. doi: 10.1016/j.biortech.2011. 01.082

Zhang, W., Wu, S., Guo, J., Zhou, J., and Dong, R. (2015). Performance and kinetic evaluation of semi-continuously fed anaerobic digesters treating food waste: role of trace elements. Bioresource Technol. 178, 297-305. doi: 10.1016/j.biortech.2014.08.046

Conflict of Interest Statement: The authors declare that the research was conducted in the absence of any commercial or financial relationships that could be construed as a potential conflict of interest.

Copyright $\odot 2016$ Ariunbaatar, Esposito, Yeh and Lens. This is an open-access article distributed under the terms of the Creative Commons Attribution License (CC BY). The use, distribution or reproduction in other forums is permitted, provided the original author(s) or licensor are credited and that the original publication in this journal is cited, in accordance with accepted academic practice. No use, distribution or reproduction is permitted which does not comply with these terms. 